\title{
PERAN TATA KELOLA PERUSAHAAN DAN RISIKO PELAPORAN KEUANGAN DALAM PEMBENTUKAN KOMITE MANAJEMEN RISIKO YANG TERPISAH
}

\author{
Yessi Arifina \\ Universitas Katolik Soegijapranata
}

\begin{abstract}
This study examines the effect of board size, board independence, financial reporting risk, firm complexity, and firm size on the formation of risk management committees apart from audit committee. This study predicts the increasing number of board of size improve the supervisory function and encourage the formation of separate risk management committees. The higher the independence of the board of commissioners, the better the supervision will be and encourage the formation of separate risk management committees. The larger the company's business segments the risks faced by the company will also be greater and this will encourage the formation of separate risk management committees. Large companies have greater responsibility to shareholders than small companies. Therefore, companies are required to perform more effective oversight functions. This will encourage companies to form separate risk management committees. The results show that board size has a positive effect on the formation of separate risk management committees. Financial reporting risk negatively affect the formation of separate risk management committees. Mean while board independence, company complexity, and firm size have no effect on the formation of separate risk management committees.
\end{abstract}

Keywords: risk management, board independence, firm complexity, reporting risk.

\begin{abstract}
Abstrak
Penelitian ini menguji pengaruh ukuran dewan komisaris, independensi dewan komisaris, risiko pelaporan keuangan, kompleksitas perusahaan, dan ukuran perusahaan terhadap pembentukan komite manajemen risiko yang terpisah dari komite audit. Penelitian ini memprediksi semakin banyaknya jumlah dewan komisaris yang ada, maka akan meningkatkan fungsi pengawasan dan mendorong pembentukan komite manajemen risiko yang terpisah. Semakin tinggi independensi dewan komisaris maka pengawasan akan menjadi lebih baik dan mendorong pembentukan komite manajemen risiko yang terpisah. Semakin besar segmen bisnis yang dimiliki perusahaan maka risiko yang dihadapi oleh perusahaan juga akan semakin besar dan mendorong pembentukan komite manajemen risiko yang terpisah. Perusahaan besar memiliki tanggung jawab yang lebih besar kepada para pemegang saham dibanding perusahaan kecil sehingga perusahaan dituntut untuk menjalankan fungsi pengawasan secara lebih efektif. Ini akan mendorong perusahaan untuk membentuk komite manajemen risiko yang terpisah. Hasil penelitian menunjukkan ukuran dewan komisaris berpengaruh positif terhadap pembentukan komite manajemen risiko yang terpisah dan risiko pelaporan keuangan berpengaruh negatif terhadap pembentukan komite manajemen risiko yang terpisah. Sementara independensi dewan komisaris, kompleksitas perusahaan, dan ukuran perusahaan tidak berpengaruh terhadasp pembentukan komite manajemen risiko yang terpisah.
\end{abstract} Kata Kunci: manajemen risiko, independensi dewan komisaris, kompleksitas
perusahaan, risiko pelaporan. 


\section{PENDAHULUAN}

Komite manajemen risiko merupakan komite yang dibentuk dewan komisaris yang bertanggung jawab menentukan strategi manajemen risiko, mengevaluasi operasi manajemen risiko, menilai pelaporan keuangan dan memastikan berjalan sesuai dengan hukum dan peraturan (Desender dalam Safitri dan Meiranto, 2013).Dalam penerapannya komite manajemen risiko dibagi menjadi dua jenis yaitu komite manajemen risiko yang berdiri sendiri (terpisah) dan komite manajemen risiko gabungan (dikombinasikan dengan komite audit). Komite manajemen risiko terpisah memiliki kualitas pengendalian internal yang lebih tinggi dibandingkan dengan komite manajemen risiko gabungan. Hal ini didasarkan bahwa manajemen risiko adalah suatu proses identifikasi, pengelolaan dan pemantauan dalam meminimalkan risiko. Pratika dan Ardiyanto, (2009) berpendapat bahwa dalam menangani dan mendeteksi ancaman dan peluang yang dapat terjadi didalam entitas, perusahaan membutuhkan komite manajemen risiko dalam proses pengawasanya sehingga dapat meringankan tugas dewan direksi itu sendiri.

Para pengamat berpendapat komite manajemen risiko yang terpisah akan lebih efisien dibandingkan komite manajemen risiko yang tergabung dengan komite audit (Collier, 1993; Ruigrok et al, 2006; Turpin dan DeZoort, 1998 dalam Ratnawati, 2012).Sebagian perusahaan memandang bahwa keberadaan komite manajemen risiko yang terpisah dari komite auditdapat mengatasi tugas pengawasan manajemen risiko yang dibebankan pada komite audit lebih efisien dan efektif. Selain itu komite manajemen risiko juga dapat memberikan nilai pada perusahaan dalam peningkatan pengawasan risiko, memperkuat kualitas manajemen risiko, dan mengurangi maupun mengelola risiko yang dihadapi perusahaan secara lebih efektif. Dengan adanyakomite manajemen risiko yang terpisah dengan komite audit dalam perusahaan memberikan fungsi pengawasan manajemen risiko yang lebih baik dan efisien dibandingkan dengan komite manajemen risikoyang tergabung dengan komite audit (Collier, 1993; Ruigrok et al, 2006; Turpin dan DeZoort, 1998 dalam Ratnawati, 2012).

Andarini (2010) keberadaan komite audit dan manajemen risiko terpisah dipengaruhi signifikan dan positif oleh ukuran perusahaan. Sehingga pengadaan komite manajemen risiko terutama komite manajemen risiko terpisah dengan komite auditakan memberikan pengendalian risiko yang lebih efektifbagi perusahaan. Risiko pelaporan keuangan timbul karena perusahaan dengan proporsi aset yang lebih besar pada piutang usaha dan persediaan karena tingginya ketidakpastian dalam data akuntansi (Korosec dan Hovart, 2005 melalui Andarini dan Indira, 2012). Potensi kesalahan perhitungan yang besar ini menimbulkan risiko pelaporan yang tinggi. Subramaniam, et al., (2009) menguji pengaruh risiko pelaporan keuangan terhadap keberadaan komite manajemen risiko menemukan hubungan positif dan signifikan antara risikopelaporan terhadap komite manajemen risiko yang terpisah dari komite audit. Hasil yang sama juga dikemukakan oleh Sambera (2013) yang menguji tentang pengaruh risiko pelaporan keuangan juga berpengaruh positif signifikan terhadap komite manajemen risiko yang terpisah.

Kompleksitas suatu perusahaan membutuhkan pengawasan dan infrastruktur pengawasan yang baik. Mekanisme manajemen risiko yang efektif akan dibutuhkan ketika risiko yang dihadapi semakin besar yang diakibatkan karena semakin kompleksnyaoperasional suatu perusahaan. Penelitian Yatim (2009) membuktikan bahwa kompleksitas dari operasi perusahaan membutuhkan pengawasan yang lebih besar dari komite manajemen risiko yang secara utama berfokus untuk mengidentifikasi risiko bisnis dan menemukan cara untuk mengurangi risiko tersebut. Oleh karena itu, pengendalian internal terhadap manajemen risiko diharapkan akan lebih tinggi ketika komite manajemen risiko berdiri sendiri dibandingkan ketika bergabung dengan komite audit.Pemisahan fungsi 
ini dari komite audit bertujuan agar fungsi pengawasan dan manajemen risiko berjalan lebih efektif.

\section{TINJAUAN PUSTAKA DAN PERUMUSAN HIPOTESIS}

\section{Teori Keagenan (Agency Theory)}

Teori keagenan merupakan hubungan antara agent (manajemen suatu usaha) dan principal (pemilik usaha). Di dalam hubungan keagenan terdapat suatu kontrak dimana satu orang atau lebih (principal) memerintah orang lain untuk melakukan suatu jasa untuk mengambil suatu keputusan bagi principal maka agen diberikan wewenang ( Jensen dan Meckling, dalam Safitri 2013). Sehingga agen mempunyai lebih banyak informasi daripada pemilik usaha (asimetri informasi). Masalah muncul ketika laporan keuangan yang disusun berdasarkan prinsip-prinsip akuntansi yang berterima umum dimanfaatkan manajer untuk mempengaruhi laba yang dilaporkan (Nuhroho dan Butar Butar, 2013).

Dilihat dari perspektif agensi, terdapat dua mekanisme pengawasan manajemen yang umum, yaitu pengawasan internal dan pengawasan eksternal. Mekanisme pengawasan internal adalah dewan komisaris dan komite (Ruigrok, et al., 2006; Firth dan Rui, 2006, Chen, et al., 2009 dalam Andarini dan Januarti, 2010) sedangkan mekanisme pengawasan eksternal adalah auditor eksternal.

Masalah keagenan muncul saat terjadi benturan kepentingan dan asimetri informasi antara principal dan agent. Benturan kepentingan antara principal dan agent terjadi ketika agent tidak selalu berbuat sesuai dengan kepentingan principal sehingga menimbulkan asimetri informasi dimana salah satu pihak memiliki informasi yang lebih banyak dibandingkan pihak lainnya. Perbedaan kepentingan dan asimetri informasi inilah yang menimbulkan adanya biaya keagenan (agency cost).

Penerapan manajemen risiko dapat menurunkan biaya keagenan dan meningkatkan nilai perusahaan. Kajuter (2005) menambahkan dengan adanya manajemen risiko pada perusahaan dapat dijadikan sebagai mekanisme pengawasan dalam menurunkan asimetri informasi.

\section{Manajemen Risiko}

Manajemen risiko bertujuan untuk mengelola risiko sehingga organisasi bisa dapat bertahan. Djojosoedarso, (2003) dalam Utomo, (2012) menyatakan bahwa risiko tidak dapat dihilangkan namun risiko dapat diminimaliskan melalui manajemen risiko. Manajemen risiko adalah pelaksanaan fungsi-fungsi manajemen dalam penanggulangan risiko, termasuk risiko yang dihadapi oleh organisasi atau perusahaan.Kesadaran yang tinggi terhadap manajemen risiko sebagian besar sebagai akibat dari beberapa bencana yang dihadapi perusahaan dan kegagalan bisnis yang tidak diharapkan (Walker, et al. dalam Yatim, 2009). Oleh karena itu, setiap perusahaan membutuhkan manajemen risiko untuk mengurangi dan menangani setiap risiko perusahaan yang mungkin muncul.

Manajemen risiko perusahaan membuat pengelolaan ketidakpastian menjadi lebih efektif terkait dengan risiko dan peluang dengan tujuan untuk mempertinggi nilai. Dengan adanya manajemen risiko perusahaan dapat mengenali atau mengetahui risiko apa yang sedang dihadapi perusahaan tersebut. Sehingga melalui manajemen risiko perusaha dapat menanggulangi risiko.

Komite manajemen risiko adalah komite yang dibentuk oleh dewan direksi. Komite manajemen risiko bertanggungjawab kepada dewan komisaris dan membantu mereka dalam seluruh aspek pengawasan manajemen risiko perusahaan (Alijoyo dan Zaini, dalam Utomo 2012). 
Perkembangan komite manajemen risiko di Indonesia sudah sangat meningkat, khususnya di industri perbankan setelah Bank Indonesia mengeluarkan peraturan mengenai wajib dibentuk komite pemantau risiko yang tercantum dalam Peraturan Bank Indonesia No.8/4/PBI/2006. Istilah komite manajemen risiko di sektor perbankan disebut dengan komite pemantau risiko. Peraturan tersebut berisi tentang penerapan GCG bagi bank umum. Pembentukan Komite Pemantau Risiko ini merupakan salah satu syarat yang harus dipenuhi oleh bank umum dan harus dibentuk paling lambat pada akhir 2007. Bagi bank yang belum membentuk komite tersebut akan dikenakan sanksi dari Bank Indonesia.

Dengan adanya pembentukan komite manajemen risiko dapat ditetapkannya kebijakan risiko yang sesuai dengan keadaan yang dihadapi oleh perusahaan untuk membantu dewan direksi mengelola risiko. Dalam KPMG, (2001) komite manajemen risiko sebagai komite dibawah dewan komisaris yang memberikan pelajaran manajemen risiko pada tingkat dewan mengenai indentifikasi dan strategi risiko yang tepat.

Komite manajemen risiko dalam pembentukannya dipisahkan menjadi dua yang terdiri dari komite manajemen risiko yang bergabung dengan komite audit dan manajemen risiko yang terpisah dengan komite audit. Komite yang terpisah akan lebih efektif dikarenakan akan dapat lebih fokus dalam menangani risiko yang sedang dihadapi dan memiliki pengendalian intern yang lebih tinggi dari komite yang tergabung.

Komite manajemen risiko yang terpisah dari komite auditakandapat memberikan lebih banyak waktu dan usaha untuk menggabungkan berbagai risiko yang terjadi di perusahaan secara luas dan memberikan penilaian pengendalian secara keseluruhan (Subramaniam, et al., dalam Utomo, 2013). Sehingga akan lebih baik perusahaan menerapkan atau menggunakan komite manajemen risiko yang terpisah dari komite audit karena akan lebih efektif dalam menangani risiko yang dihadapi perusahaan.

\section{Pengembangan Hipotesis}

Ukuran dewan yang lebih besar akan lebih memungkinkan memiliki anggota-anggota komisaris dengan keterampilan yang diperlukan untuk mengkoordinasikan dan menjadi terlibat dalam komite - komite yang dibentuk dewan komisaris, yang ditunjukkan untuk manajemen risiko (Hanifah, 2013). Ukuran dewan yang lebih besar memungkinkan untuk pembentukan berbagai komite termasuk komite manajemen risiko. (Badriyah, dkk.,2015).

Hasil penelitian yang dilakukan oleh Ratnawati dan Setyobudi (2010) menunjukan bahwa ukuran dewan komisaris secara positif signifikan mempengaruhi komite manajemen risiko terpisah.Artinya ukuran dewan yang besar terjamin terbentuknya komite baru secara sukarela. Semakin besarnya ukuran dewan akan memberikan sumber daya keahlian, yang dapat menambah kualitaspengawasanperusahaan. Hasil penelitian ini mendukung penelitian Badriyah, dkk (2015), dan Diani (2013) yangmenemukan bahwa ukuran dewan komisaris secara positif signifikan mempengaruhi komite manajemen risiko terpisah.

Dengan demikian, semakin banyaknya jumlah dewan komisaris yang ada, maka akan membuat mereka bekerja lebih bersungguh-sungguh dalam meningkatkan pengawasan. Mendorong dewan komisaris untuk berpikir bagaimana agar dapat membuat pengawasan tersebut menjadi lebih efektif lagi, sehingga diperlukannya suatu komite manajemen risiko yang berdiri sendiri atau terpisah dari komite audit, agar dapat menjalankan tugasnya masingmasing dengan lebih efektif dan dapat meningkatkan pengawasannya menjadi lebih baik.

Sehingga semakin besar jumlah dewan komisaris semakin besar pula kemungkinan perusahaan untuk membentuk komite manajemen risiko terutama yang terpisah dengan komite audit. Berdasarkan penjelasan tersebut, hipotesis yang diusulkan berikut ini:

$\mathrm{H}_{1}$ : Semakin besar ukuran dewan komisaris, semakin besar pula kemungkinan perusahaan membentuk komite manajemen risiko yang terpisah. 
Badriyah, dkk (2015) mengungkapkan bahwa perusahaan dengan proporsi yang tinggi dari komisaris manajemen risiko independen cenderung lebih peduli dengan risiko perusahaan dibandingkan dengan proporsi rendah komisaris independen. Kehadiran komisaris independen dapat menambahkan kualitas pengawasan dalam perusahaan, dan dapat mendorong perusahaan melaksanakan corporate governanceyang baik lebih. Literatur terdahulu menemukan bahwa independensi Dewan Komisaris terhadap manajemen puncak meningkatkan keefektifan pengelolaan perusahaan (Butar Butar, 2014).

Proporsi komisaris independen yang tinggi maka pengawasan akan menjadi lebih baik dengan pengecekan yang independen, dan lebih cenderung menyediakan pengawasan yang lebih besar pada aktivitas manajemen risiko perusahaan. Komisaris independen merupakan pihak yang berasal dari luar perusahaan. Perusahaan yang memiliki lebih besar jumlah anggota dewan komisaris yang berasal dari luar perusahaan, akan menunjukan semakin tingginya independensi dewan komisaris.

Hasil penelitian yang dilakukan oleh Ratnawati (2012) menunjukan bahwa proporsi komisaris independen secara positif signifikan mempengaruhi komite manajemen risiko terpisah. Hasil penelitian ini mendukung penelitian Badriyah, dkk (2015), dan Pincus, et al. (1989) dalam Subramaniam, et al., (2009) yang menyatakan bahwa proporsi komisaris independen signifikan mempengaruhi komite manajemen risiko terpisah. Independensi dewan komisaris yang tinggiakan memudahkan perusahaan dalam rangka meningkatkan pembentukankomite manajemen risiko terpisah. Maka hipotesis dalam penelitian ini :

\section{$\mathrm{H}_{2}$ : Semakin tinggi independensi dewan komisaris, semakin tinggi pula pembentukan komite manajemen risiko yang terpisah.}

Menurut Korosec dan Horvart, dalam Diani (2013) perusahaan dengan proporsi aset yang lebih besar pada piutang usaha dan persediaan berkecenderungan memiliki risiko pelaporan keuangan yang lebih tinggi, dikarenakan ketidakpastian dalam data akuntansi.Semakin besar persediaan yang dimiliki perusahaan semakin perusahaan memiliki alokasi biaya-biaya pabrik yang cukup besar dan juga dengan persediaan yang dimiliki akan mengalami penyusutan yang dapat mengurangi harga perolehan. Dengan piutang yang besar semakin perusahaan akan menghadapi risiko-risiko seperti, risiko piutang tidak tertagih, risiko hanya dibayarkannya separuh dari piutang, keterlambatan pembayaran pelunasan piutang dan berbagi risiko lainnya yang dapat merugikan perusahaan. Sehingga potensi kesalahan perhitungan dapat terjadi dikarenakan risiko pelaporan yang tinggi.

Risiko pelaporan keuangan akan menentukan risiko yang dihadapi oleh perusahaan dan kemudian mendorong kewajiban untuk membentuk komite manajemen risiko yang terpisah. Dikarenakan semakin tinggi risiko pelaporan keuangan, semakin tinggi pula ketidakpastian data akuntansi yang disajikan sehingga mendorong perusahaan untuk membentuk komite manajemen risiko yang terpisah.Diharapkan dengan adanya komite manajemen risiko yang terpisah dapatmenghasilkan pengawasan risiko dengan kinerja yang lebih efektif.

Hasil penelitian Subramaniam, et al., (2009) yang menyatakan bahwa keberadaan komite manajemen risiko terpisah secara signifikan diperngaruhi positif dengan risiko pelaporan keuangan. Ini sejalan dengan yang diteliti oleh Badriyah, dkk (2015) dan Dyaksa (2012), yang didalam pernyataannya menyebutkan bahwa komite manajemen risiko yang terpisah dari komite auditdipengaruhi secara positif oleh risiko pelaporan keuangan. Maka hipotesis dalam penelitian ini :

$\mathrm{H}_{3}$ : Semakin tinggi risiko pelaporan keuangan, semakin tinggi pula kemungkinan perusahaan membentuk komite manajemen risiko yang terpisah. 
Kompleksitas sebuah perusahaan dapat dilihat dari jumlah segmen bisnis yang dimiliki oleh perusahaan. Menurut Subramaniam et al., dalam Sambera (2013) apabila kompleksitas yang besar maka risiko juga akan meningkat sehingga menuntutpengawasan risiko yang lebih besar pula.

Penelitian Yatim (2009) membuktikan bahwa kompleksitas dari operasi perusahaan membutuhkan pengawasan yang lebih besar dari komite manajemen risiko yang secara utama berfokus untuk mengidentifikasi risiko bisnis dan menemukan cara untuk mengurangi risiko tersebut. Ramadhani, dkk, (2015) menemukan bahwa kompleksitas pengaruh positif terhadap penerapan komite manajemen risiko terpisah. Ini sejalan dengan penelitian yang dilakukan oleh Badriyah, dkk (2015)bahwa kompleksitas pengaruh positif terhadap komite manajemen risiko terpisah dari komite audit.

Semakin besar segmen bisnis yang dimiliki perusahaan maka risiko yang dihadapi oleh perusahaan juga akan semakin besar, ini dikarenakan perusahaan memiliki cabangcabang perusahaan yang semakin luas dan akan membutuhkan mekanisme manajemen risiko yang efektif.Hal ini akan mendorongperusahaan memerlukan komite manajemen risiko yang terpisah dengan komite audit, sehingga dapat memberikan pengawasan yang lebih efektif.Maka hipotesis dalam penelitian ini :

\section{$\mathrm{H}_{4}$ : Semakin besar kompleksitas perusahaan, semakin besar pula kemungkinan perusahaan membentuk komite manajemen risiko yang terpisah.}

Ukuran perusahaan dapat menggambarkan besar kecilnya skala ekonomi suatu perusahaan.Menurut Jensen dan Meckling dalam Andarini dan Januarti (2012)perusahaan dengan ukuran besar berkecenderungan memiliki potensi dalam masalah agensi yang lebih besar, karena lebih sulit untuk melakukan tindakan pengawasan.Perusahaan dimungkinkan memiliki tanggung jawab yang lebih besar kepada para pemegang saham dibanding perusahaan kecil karena dasar kepemilikan yang lebih luas, sehingga perusahaan dituntut untuk menjalankan fungsi pengawasan secara lebih efektif

Dalam penelitian Andarini dan Januarti (2012) menemukan bahwa ukuran perusahaan berhubungan signifikan positif dengan komite manajemen risiko terpisah dengan audit.Sejalan dengan penelitian yang telah dilakukan oleh Wahyuni dan Harto (2012) dan Ratnawati dan Setyobudi (2010) yang menunjukan bahwa ukuran perusahaan berhubungan signifikan positif dengan komite manajemen risiko terpisah dengan audit.

Dengan demikian, perusahaan dengan ukuran besar, perusahaan dimungkinkan memiliki tanggung jawab yang lebih besar kepada para pemegang saham dibanding perusahaan kecil karena dasar kepemilikan yang lebih luas, sehingga perusahaan dituntut untuk menjalankan fungsi pengawasan secara lebih efektif. Sehingga semakin besar ukuran perusahaan semakin besar puladorongan membentuk komite manajemen risiko yang terpisah dengan komite audit, yangdinilai lebih efektif dalam pengawasan risiko.Maka hipotesis dalam penelitian ini

H5: Semakin besar ukuran perusahaan, semakin besar pula kemungkinan perusahaan membentuk komite manajemen risiko yang terpisah.

\section{METODE PENELITIAN}

\section{Populasi dan Sampel Penelitian}

Populasi adalah seperangkat unit yang menjadi perhatian peneliti (Butar Butar, 2007). Penelitian ini menggunakan populasi semua jenis perusahaan yang terdaftar di Bursa Efek Indonesia (BEI) tahun 2010-2014. Sampel adalah sebagian dari populasi yang akan diteliti. Metode penggambilan sampel yang digunakan adalah dengan menggunakan metode purposive sampling. Purposive sampling adalah pengambilan sampel dari populasi 
berdasarkan kriteria tertentu (Jogiyanto, 2012). Adapun kriteria sampel yang digunakan sebagai berikut:

1. Perusahaan yang terdaftar di Bursa Efek Indonesia (BEI) tahun 2010-2014.

2. Laporan tahunan dan laporan keuangan perusahaan dapat diperoleh dari sumbersumber data yang digunakan peneliti.

3. Laporan tahunan dan laporan keuangan perusahaan memberikan informasi yang diperlukan untuk mengukur variabel-variabel peneliti.

Berdasarkan kriteria pengambilan sampel diatas, maka sampel dalam penelitian ini dapat dilihat pada tabel 3.1 sebagai berikut:

Tabel 3.1 menunjukan data sampel dari tahun 2010 sampai tahun 2014 terdiri dari 31 perusahaan pada tahun 2010, 58 perusahaan pada tahun 2011, 63 perusahaan pada tahun 2012, 74 perusahaan pada tahun 2013, 83 perusahaan pada tahun 2014 dan total dari keseluruhan sampel adalah 309 perusahaan.

Tabel 3.1 Kriteria Pengambilan Sampel

\begin{tabular}{|l|l|l|l|l|l|l|}
\hline Kriteria Pengambilan Sampel & $\mathbf{2 0 1 0}$ & $\mathbf{2 0 1 1}$ & $\mathbf{2 0 1 2}$ & $\mathbf{2 0 1 3}$ & $\mathbf{2 0 1 4}$ & Total \\
\hline $\begin{array}{l}\text { Perusahaan yang terdaftar di BEI tahun } \\
\text { 2010-2014 }\end{array}$ & 428 & 448 & 466 & 499 & 510 & 2351 \\
\hline $\begin{array}{l}\text { Laporan tahunan perusahaan yang tidak } \\
\text { tersedia dalam sumber data yang } \\
\text { digunakan }\end{array}$ & $(24)$ & $(28)$ & $(26)$ & $(19)$ & $(20)$ & $(117)$ \\
\hline $\begin{array}{l}\text { Perusahaan yang tidak memiliki komite } \\
\text { manajemen risiko }\end{array}$ & $(373)$ & $(362)$ & $(377)$ & $(406)$ & $(408)$ & $(1926)$ \\
\hline Jumlah Sampel Perusahaan & $\mathbf{3 1}$ & $\mathbf{5 8}$ & $\mathbf{6 3}$ & $\mathbf{7 4}$ & $\mathbf{8 3}$ & $\mathbf{3 0 9}$ \\
\hline
\end{tabular}

Sumber: Data Sekunder, 2016

Tabel 3.2. Perusahaan Yang Memiliki Komite Manajemen Risiko

\begin{tabular}{|l|l|l|l|l|l|l|}
\hline Kriteria Pengambilan Sampel & $\mathbf{2 0 1 0}$ & $\mathbf{2 0 1 1}$ & $\mathbf{2 0 1 2}$ & $\mathbf{2 0 1 3}$ & $\mathbf{2 0 1 4}$ & total \\
\hline $\begin{array}{l}\text { Perusahaan yang komite manajemen } \\
\text { risiko yang terpisah dengan komite audit }\end{array}$ & 7 & 28 & 29 & 30 & 29 & 123 \\
\hline $\begin{array}{l}\text { Perusahaan yang komite manajemen } \\
\text { risiko yang tergabung dengan komite } \\
\text { audit }\end{array}$ & 24 & 30 & 34 & 44 & 54 & 186 \\
\hline Jumlah Sampel Perusahaan & $\mathbf{3 1}$ & $\mathbf{5 8}$ & $\mathbf{6 3}$ & $\mathbf{7 4}$ & $\mathbf{8 3}$ & $\mathbf{3 0 9}$ \\
\hline
\end{tabular}

Tabel 3.2 menunjukan kriteria sampel perusahaan yang memiliki komite manajemen risiko yang terpisah dengan komite audit dari tahun 2010 sampai 2014 sebanyak 123 perusahaan, dan sampel perusahaan yang komite manajemen risikonya tergabung dengan komite audit dari tahun 2010 sampai 2014 adalah sebanyak 186 perusahaan.

Data yang digunakan dalam penelitian ini adalah data sekunder, yaitu data penelitian yang diperoleh peneliti dari pihak lain yang berkaitan dengan data yang akan diambil. Data dalam penelitian ini adalah laporan tahunan dan laporan keuangan perusahaan yang terdaftar di Bursa Efek Indonesia (BEI) dari tahun 2010-2014. Sumber data diperoleh melalui Pojok Bursa Efek Indonesia UNIKA Soegijapranata; kantor perwakilan BEI Jl. M.H. Thamrin No 152, Semarang; situs resmi Bursa Efek Indonesia (BEI) yaitu www.idx.co.id; Indonesian 
Capital Market Directory (ICMD); web masing-masing perusahaan yang menjadi sampel penelitian serta status hubungan politik dari proses penulusuran pada www.google.com.

\section{Pengukuran Variabel}

Penelitian ini menggunakan komite manajemen risiko yang terpisah dengan komite audit sebagai variabel dependen.Variabel komite manajemen risiko yang terpisah diukur menggunakan variabel dummy, yang bernilai 1 jika perusahaan mengungkapkan keberadaan komite manajemen risiko yang terpisah dengan komite audit dalam laporan tahunannya dan 0 jika jika perusahaan mengungkapkan keberadaan komite manajemen risiko yang tergabung dengan komite audit dalam laporan tahunannya.

Ukuran dewan komisaris adalah jumlah total anggota dewan komisaris termasuk komisaris independen yang terdapat pada perusahaan (Dyaksa, 2012).Dalam perusahaan sektor finansial jumlah anggota Dewan Komisaris telah diatur dalam peraturan Menteri Keuangan No. 152/PMK.010/2012, PBI No. 8/4/PBI/2006 yang mengatur tentang pedoman GCG menyatakan bahwa jumlah anggota Dewan Komisaris sekurang-kurangnya tiga orang atau paling banyak sama dengan jumlah anggota Direksi.

Ukuran dewan komisaris akan berdampak pada kualitas keputusan dan kebijakan yang telah dibuat dalam rangka mengefektifkan pencapaian tujuan organisasi (Syakhroza, 2004 dalam Dyaksa, 2012). Variabel ukuran dewan komisaris diukur dengan.

$$
\text { UkrnDK }=\Sigma \text { Anggota Dewan Komisaris }
$$

Independensi dewan komisaris merupakan anggota dewan komisaris yang tidak memiliki hubungan keluarga, bisnis dan urusan lainnya dengan perusahaan.Independensi dewan komisaris beranggotakan dewan komisaris yang berasal dari luar perusahaan dan dari dalam perusahaandan berfungsi untuk menilai kinerja perusahaan secara luas dan keseluruhan (Susiana dan Herawaty, 2007).

Keberadaan komisaris independen dimaksudkan untuk menciptakan keadaan yang lebih objektif dan independen, dan juga untuk menjaga "fairness" serta mampu memberikan keseimbangan antara kepentingan pemegang saham mayoritas dan perlindungan terhadap kepentingan pemegang saham minoritas, bahkan kepentingan para stakeholders lainnya (Alijoyo dan Zaini, 2004 dalam Dyaksa, 2012).Variabel independensi dewan komisaris diukur melalui persentase antara anggota komisaris independen dengan total dewan komisaris perusahaan .

$$
\text { IndDK }=\frac{\Sigma \text { Komisaris Independen }}{\Sigma \text { Dewan komisaris }}
$$

Risiko pelaporan keuangan ditunjukan dengan proporsi piutang usaha dan persediaan yang lebih besar pada aset. Saat itu perusahaan akan berkecenderungan memiliki risiko pelaporan keuangan yang lebih tinggi (Koreses dan 27 Horvat, 2005 dalam Diani 2013).Piutang usaha dan persediaan mempunyai kemungkinan kesalahan dalam penilaian, sehingga dapat meningkatkan risiko pelaporan keuangan (Utomo, 2012).

Hal ini dikarenakan semakin besarnya piutang dan persediaan yang dimiliki perusahaan, mengakibatkan munculnya risiko-risiko seperti risiko tidak tertagih piutang, risiko keterlambatan pembayaran pelunasan piutang dan juga persediaan yang berlebih mengakibatkan biaya alokasi dan kemungkinan akan mengalami kerusakan atau usang, sehingga perusahaan memilik ketidakpastian data. Dalam penelitian ini variabelrisiko pelaporan keuangan diukur dengan menjumlah piutang dan persediaan dibagi dengan total aset. 


\section{RisPK $=$ EPiutang Usaha + Persediaan \\ $\sum$ Total Aset}

\section{Kompleksitas Perusahaan}

Kompleksitas dari sebuah perusahaan adalah jumlah segmen bisnis yang dimiliki perusahaan tersebut. Organisasi dengan jumlah segmen bisnis yang besar biasanya memiliki bermacam-macam produksi, departemen-departemen atau strategi pemasaran (Subramaniam et al., 2009).Kompleksitas yang lebih besar akan meningkatkan risiko yang ditanggung oleh perusahaan. (Subramaniam, et al., dalam Dyaksa, 2012).Dalam penelitian ini variabelkompleksitas diukur dengan menjumlah segmen bisnis atau usaha yang dimiliki oleh perusahaan.

KomPer $=\Sigma$ Segmen bisnis perusahaan

\section{Ukuran Perusahaan}

Menurut Subramaniam, et al., dalam Wahyuni (2012) ukuran perusahaan merupakan gambaran besar kecilnya suatu perusahaan. Semakin besar ukuran perusahaan maka potensi risikonya juga semakin besar. Indikator untuk mewakiliukuran perusahaan adalah total aktiva yang dimiliki perusahaan. Dalam penelitian ini variabel ukuran perusahaan diukur dengan menggunakan logaritma natural total aset perusahaan.

\section{Model Penelitian}

$$
\text { Ukuran }=\text { Logaritma Natural Total Aset }
$$

Penelitian ini menggunakan regresi logistik karena variabel terikatnya merupakan dummy, yaitu komite manajemen risiko yang terpisah dengan komite audit di perusahaan atau komite manajemen risiko yang tergabung dengan komite audit di perusahaan. Model regresi berikut ini digunakan untuk menguji hubungan komite manajemen risiko yang terpisah dan karakteristik dewan komisaris serta karakteristik perusahaan. Persamaan regresi yang digunakan untuk mengetahui hubungan komite manajemen risiko yang terpisahdengan variabel-variabel independen adalah sebagai berikut:

$$
\begin{aligned}
\mathrm{RMC}= & \mathrm{a}+\mathrm{b} 1 \mathrm{UkrnDK}+\mathrm{b} 2 \text { IndDK }+\mathrm{b} 3 \mathrm{RisPK}+ \\
& \text { B4 KomPer }+\mathrm{b} 5 \text { Ukuran }+\mathrm{e}
\end{aligned}
$$

Keterangan:

$\begin{array}{ll}\text { RMC } & \text { : Risk Management Committee } \\ & \text { Variabel dummy : 0 = tergabung dan } 1=\text { terpisah } \\ \text { UkrnDK } & \text { : Ukuran Dewan Komisaris, } \\ & \text { Diukur dengan proporsi jumlah dewan komisaris } \\ \text { IndDK } & \text { : Independensi Dewan Komisaris } \\ \text { RisPK } & \text { : Risiko Pelaporan Keuangan } \\ & \text { (Total piutang + persediaan) / total aset } \\ \text { KomPer } & : \text { Kompleksitas Perusahaan, diukur dengan jumlah segmen } \\ \text { Ukuran } & \text { : Ukuran Perusahaan, menggunakan LN } \\ \text { e } & : \text { Error }\end{array}$




\section{HASIL DAN PEMBAHASAN}

\section{Statistik Deskriptif}

Statistik deskriptif memberikan gambaran tentang nilai minimum, maksimum, rata-rata, dan deviasi standar tentang masing-masing variabel dalam penelitian.

Tabel 3.3

Statistik Deskriptif

\begin{tabular}{|l|r|r|r|r|r|}
\hline & $\mathrm{N}$ & Minimal & Maksimal & Rata-rata & $\begin{array}{c}\text { Deviasi } \\
\text { Standar }\end{array}$ \\
\hline UKrnDK & 309 & 2.00 & 10.00 & 4.93 & 1.66 \\
IndDK & 309 & 0.20 & 1.00 & 0.47 & 0.14 \\
RisPK & 309 & 0.01 & 0.97 & 0.46 & 0.26 \\
KomPer & 309 & 1.00 & 7.00 & 2.80 & 1.23 \\
ln_uk & 309 & 14.15 & 30.59 & 21.13 & 4.71 \\
Valid N & 309 & & & & \\
(listwise) & & & & \\
\hline
\end{tabular}

Berdasarkan table 3.3 variabel ukuran dewan komisaris (UkrnDK) memiliki rata-rata sebesar 4,93dengan nilai minimal 2 dan maksimal sebesar 10 . Hal ini menunjukan bahwa rata-rata perusahaan dalam penelitian ini memiliki dewan komisaris sebanyak 4-5 orang. Variabel independensi dewan komisaris (IndDK) memiliki rata-rata sebesar 0,47dengan nilai minimal dan maksimal sebesar 0,20 dan 1,00. Hal ini menunjukan bahwa perusahaan memiliki persentase komisaris independen paling rendah $20 \%$ dan paling tinggi $100 \%$ dengan rata-rata sebesar $47 \%$.

Variabel risiko pelaporan keuangan (RisPK) memiliki rata-rata sebesar 0,46 dengan nilai minimal dan maksimal sebesar 0,01dan 0,97. Hal ini menunjukan bahwaperusahaan sampel penelitian menghadapi risiko atas pelaporan keuangan yang melibatkan persediaan dan piutang usaha terhadap total asset sebesar $46 \%$. Variabel ini diukur dengan proporsi jumlah persediaan dan piutang terhadap total asset, semakin tinggi proporsinya maka semakin berisiko, karena persediaan yang besar dan piutang yang besar. Sehingga dapat merugikan perusahaan, apabila risiko perusahaan mendekati angka $100 \%$ berarti sangat tinggi, tapi penelitiaan ini menunjukan hasil rata-rata hanya $46 \%$ yang berarti masih moderat atau masih dalam tingkat sedang.

Variabel kompleksitas perusahaan (KomPer) memiliki rata-rata 2,80 yang artinya rata-rata perusahaan dalam penelitian ini memiliki total segmen sebesar 2-3 dengan nilai minimal dan maksimal sebesar 1 dan 7.Variabel ukuran perusahaan (Ukuran) memiliki rata-rata 21,13dengan nilai minimal dan maksimal sebesar 14,15 dan 30,59 .

Tabel 3.4

Frekuensi Variabel Komite Manajemen Risiko

\begin{tabular}{|ll|r|r|r|}
\hline & Frequency & Percent & $\begin{array}{c}\text { Cumulative } \\
\text { Percent }\end{array}$ \\
\hline Valid & tergabung & 181 & 58.6 & 58.6 \\
& terpisah & 128 & 41.4 & 100.0 \\
& Total & 309 & 100.0 & \\
\hline
\end{tabular}


Dalam penelitian ini perusahan yang memiliki komite manajemen risiko yang terpisah dengan komite audit diberi nilai 1 dan perusahaan yang memiliki komite manajemen risiko tergabung dengan komite audit diberi nilai 0. Dari table 3.4 dapat diketahui bahwa $41,4 \%$ atau 128 perusahaan dalam penelitian ini memiliki komite manajemen risiko yag terpisah dengan komite audit. Sedangkan 58,6\% atau 181 perusahaan dalam penelitian ini memiliki komite manajemen risiko yang tergabung dengan komite audit.

\section{Menilai Kelayakan Model Regresi}

Analisis pertama yang dilakukan adalah menilai kelayakan model regresi logistik yang digunakan dengan menggunakan Hosmer and Lemeshow Test.

Tabel 3.5

HasilUji Hosmer and Lemeshow's Goodness of Fit Test

\begin{tabular}{|l|r|r|r|}
\hline Step & Chi-square & df & \multicolumn{1}{c|}{ Sig. } \\
\hline 1 & 14.804 & & 8 \\
& & & 0.063 \\
\hline
\end{tabular}

Hasil uji pada output Hosmer and Lemeshow Goodness of Fit menunjukan nilai sebesar 14,804dengan probabilitas signifikansi 0,063 lebih besar dari 0,05. Sehingga dapat disimpulkan bahwa model Fit telah mampu untuk menjelaskan data dan model regresi ini dapat digunakan untuk analisis berikutnya.

\section{Hasil Penelitian}

Model regresi berikut ini digunakan untuk menguji hubungan komite manajemen risiko yang terpisah dan karakteristik dewan komisaris serta karakteristik perusahaan. Persamaan regresi yang digunakan untuk mengetahui hubungan komite manajemen risiko yang terpisahdengan variabel-variabel independen.

Tabel 3.6 Hasil Analisis Regresi Logistik.

\begin{tabular}{|l|c|c|c|r|r|r|r|}
\hline & \multicolumn{1}{|c|}{ B } & \multicolumn{1}{c|}{ S.E. } & Wald & df & \multicolumn{1}{c|}{ Sig. } & \multicolumn{1}{c|}{ Sig/2 } & Exp(B) \\
\hline UKrnDK & 0.235 & 0.077 & 9.167 & 1 & 0.002 & 0.001 & 1.264 \\
IndDK & -0.312 & 0.955 & 0.107 & 1 & 0.744 & 0.372 & 0.732 \\
RisPK & -1.365 & 0.485 & 7.935 & 1 & 0.005 & 0.002 & 0.255 \\
KomPer & -0.063 & 0.100 & 0.402 & 1 & 0.526 & 0.219 & 0.938 \\
ln_uk & -0.001 & 0.001 & 0.002 & 1 & 0.968 & 0.484 & 0.999 \\
Constant & -0.549 & 0.990 & 0.307 & 1 & 0.579 & 0.289 & 0.578 \\
\hline
\end{tabular}

Berdasarkan tabel 3.6 dapat diketahui bahwa variabel ukuran dewan komisaris (UkrnDK) memiliki nilai koefisien sebesar $+0,235$ dan nilai signifikansi $0,001<0,05$. Hal ini menunjukan bahwa hipotesis pertama diterima, dan mengindikasikan bahwa ukuran dewan komisaris berpengaruh secara positif terhadap pembentukan komite manajemen risiko yang terpisah dengan komite audit. Artinya semakin besar ukuran dewan komisaris, semakin besar pula kemungkinan perusahaan membentuk komite manajemen risiko yang terpisah.

Variabel independensi dewan komisaris (IndDK) memiliki nilai koefisien sebesar 0,312 dan nilai signifikansi $0,372>0,05$. Hal ini menunjukan bahwa hipotesis kedua ditolak, dan mengindikasikan bahwa independensi dewan komisaris tidak berpengaruh terhadap pembentukan komite manajemen risiko yang terpisah dengan komite audit. 
Variabel risiko pelaporan keuangan (RisPK) memiliki nilai koefisien sebesar -1,365 dan nilai signifikansi $0,002<0,05$. Hal ini menunjukan bahwa hipotesis risiko pelaporan keuangan berpengaruh signifikan secara negatifterhadap pembentukan komite manajemen risiko yang terpisah dengan komite audit. Hal ini berbeda dengan hipotesis yang diteliti yaitu semakin tinggi risiko pelaporan keuangan, semakin tinggi pula kemungkinan perusahaan membentuk komite manajemen risiko yang terpisah, sehingga risiko pelaporan keuangan berpengaruh positif terhadap pembentukan komite manajemen risiko yang terpisah dengan komite audit. Sehingga hipotesis risiko pelaporan keuangan ditolak.

Variabel kompleksitas perusahaan (KomPer) memiliki nilai koefisien sebesar -0,063 dan nilai signifikansi 0,219>0,05. Hal ini menunjukan bahwa hipotesis keempat ditolak, dan mengindikasikan bahwa kompleksitas perusahaan tidak berpengaruh terhadap pembentukan komite manajemen risiko yang terpisah dengan komite audit.

Variabel ukuran perusahaan (Ukuran) memiliki nilai koefisien sebesar -0,001 dan nilai signifikansi $0,484>0,05$. Hal ini menunjukan bahwa hipotesis kelima ditolak, dan mengindikasikan bahwa ukuran perusahaan tidak berpengaruh terhadap pembentukan komite manajemen risiko yang terpisah dengan komite audit.

\section{Pembahasan}

Berdasarkan hasil output SPSS pada tabel 4.8, diketahui bahwa ukuran dewan komisaris berpengaruh terhadap pembentukan komite manajemen risiko yang terpisah. Hal ini dapat dilihat dari nilai signifikansi untuk ukuran dewan komisaris yang lebih kecil dari 0,05 . Dengan demikian hasil penelitian ini mendukung hipotesis yang diajukan, yaitu terdapat pengaruh signifikan antara ukuran dewan komisaris dengan komite manajemen risiko yang terpisah. Maka dapat dikatakan bahwa hipotesis pertama diterima.

Semakin banyaknya jumlah dewan komisaris yang ada, maka akan membuat mereka bekerja lebih bersungguh-sungguh dalam meningkatkan pengawasan. Dan akan mendorong dewan komisaris untuk berpikir bagaimana agar dapat membuat pengawasan tersebut menjadi lebih efektif dan dapat ditingkatkan, sehingga diperlukannya suatu komite manajemen risiko yang berdiri sendiri atau terpisah dari komite audit, agar dapat menjalankan tugasnya masing-masing dengan lebih efektif dan dapat meningkatkan pengawasannya menjadi lebih baik.

Hasil penelitian ini juga didukung penelitian Badriyah, dkk (2015), dan Diani (2013) yang menemukan bahwa ukuran dewan komisaris secara positif signifikan mempengaruhi komite manajemen risiko terpisah. Artinya semakin besarnya ukuran dewan akan memberikan sumber daya keahlian, yang dapat menambah kualitas pengawasan perusahaan dan mendorong untuk membentuk komite baru yaitu komite manajemen risiko yang terpisah dengan komite audit dalam peningkatan pengawasannya.

Berdasarkan pada hasil pengujian hipotesis kedua pada tabel 4.8 diketahui bahwa independensi dewan komisaris tidak memiliki pengaruh terhadap komite manajemen risiko yang terpisah. Hal ini disebabkan karena nilai signifikansi untuk variabel ini adalah 0,372lebih besar dari 0,05. Maka dapat dikatakan bahwa hipotesis kedua ditolak dan hasil penelitian ini tidak mendukung hipotesis yang diajukan. Dengan demikian independensi dewan komisaris tidak berpengaruh terhadap pembentukan komite manajemen risiko yang terpisah dengan komite audit.

Dewan komisaris independen merupakan komisaris yang tidak ada hubungan keluarga atau hubungan bisnis dengan direksi maupun pemegang saham yang dapat mempengaruhi kemampuannya untuk bertindak independen atau bertindak semata-mata demi kepentingan perusahan. Dewan komisaris independen berfungsi untuk menilai kinerja perusahaan secara luas dan keseluruhan. Sehingga belum mampu untuk mendominasi kebijakan yang diambil oleh dewan komisaris, khususnya tentang pembentukan komite 
baru.Dan dalam memutuskan komite terpisah atau tergabung, tidak berpengaruh dengan komposisi dewan komisaris independen.Dewan komisaris independen semata-mata hanya untuk pengambilan keputusan dalam menanggulangi resiko mendatang yang dihadapi perusahaan.Hasil penelitian ini tidak mendukung penelitian Badriyah, dkk (2015), dan Pincus, et al. (1989) dalam Subramaniam, et al., (2009) yang menyatakan bahwa proporsi komisaris independen signifikan mempengaruhi komite manajemen risiko terpisah.

Berdasarkan pada hasil pengujian hipotesis ketiga pada tabel 4.8 diketahui nilai signifikansi untuk variabel ini adalah 0,002 lebih kecil dari 0,05. Hal ini menunjukan bahwa hipotesis risiko pelaporan keuangan berpengaruh signifikan secara negatif terhadap pembentukan komite manajemen risiko yang terpisah dengan komite audit. Hal ini berbeda dengan hipotesis yang diteliti yaitu semakin tinggi risiko pelaporan keuangan, semakin tinggi pula kemungkinan perusahaan membentuk komite manajemen risiko yang terpisah, sehingga risiko pelaporan keuangan berpengaruh positif terhadap pembentukan komite manajemen risiko yang terpisah dengan komite audit. Sehingga hipotesis risiko pelaporan keuangan ditolak.Maka dapat dikatakan bahwa hipotesis ketiga ditolak dan hasil penelitian ini tidak mendukung hipotesis yang diajukan.

Persediaan dan piutang yang lebih besar tidak menjamin risiko yang akan dihadapi oleh perusahaan semakin besar pula, karena perusahaan tidak hanya menghadapi satu jenis risiko tapi juga menghadapi 8 jenis risiko lainnya seperti yang diatur dalam PMK Nomor 142/PMK/010/2009.Ini membuat tinggi rendahnya risiko pelaporan keuangan yang dihadapi perusahaan tidak dapat menentukan perusahaan untuk membentuk komite manajemen risiko yang terpisah dengan komite audit.

Hipotesis risiko pelaporan keuangan berpengaruh signifikan secara negatif terhadap pembentukan komite manajemen risiko yang terpisah. Berarti bahwa semakin rendah risiko pelaporan keuangan yang dimiliki perusahaan, semakin mendorong untuk membentuk komite manajemen risiko yang terpisah dengan audit. Hal ini dikarenakan perusahaan menghadapi berbagai jenis risiko tidak hanya risiko pelaporan keuangan, jadi ketika risiko pelaporan keuangan yang dimiliki perusahaan rendah bisa saja risiko - risiko yang lainnya tinggi, sehingga membuat perusahaan harus membentuk suatu komite untuk meningkatkan pengawasannya yaitu komite manajemen risiko yang terpisah dengan audit. Hasil penelitian ini tidak mendukung dengan yang diteliti oleh Badriyah, dkk (2015) dan Dyaksa (2012), yang didalam pernyataannya menyebutkan bahwa komite manajemen risiko yang terpisah dari komite audit dipengaruhi secara positif oleh risiko pelaporan keuangan.

Berdasarkan pada hasil pengujian hipotesis kedua pada tabel 4.8 diketahui bahwa kompleksitas perusahaan tidak memiliki pengaruh terhadap pembentukan komite manajemen risiko yang terpisah. Hal ini disebabkan karena nilai signifikansi untuk variabel ini adalah 0,219 lebih besar dari 0,05. Maka dapat dikatakan bahwa hipotesis keempat ditolak dan hasil penelitian ini tidak mendukung hipotesis yang diajukan.

Perusahaan yang kompleks atau memiliki segmen usaha lebih dari 1 (satu) tidak menjamin semakin tingginya kemungkinan perusahaan membentuk komite manajemen risiko terutama komite manajemen risiko yang terpisah. Hal ini disebabkan karena adanya kemungkinan bahwa jumlah segmen usaha kurang dapat menggambarkan kompleksitas perusahaan. Perusahaan yang hanya memiliki satu segmen usaha mungkin saja memiliki aktivitas yang kompleks karena segmen geografisnya yang tersebar luas. Hal ini pun juga dapat mengakibatkan makin kompleksnya risiko yang dihadapi perusahaan (Andarini dan Januarti, 2012). Sementara perusahaan yang memiliki 7 segmen belum tentu memiliki kompleksitas yang tinggi.Sehingga kompleksitas perusahaan tidak dapat mempengaruhi terbentuknya komite manajemen risiko yang terpisah dengan komite audit. Hasil penelitian ini tidak mendukung penelitian yang dilakukan olehRamadhani, dkk, (2015) dan Badriyah, 
dkk (2015) menemukan bahwa kompleksitas pengaruh positif terhadap penerapan komite manajemen risiko terpisah.

Berdasarkan pada hasil pengujian hipotesis kelima pada tabel 4.8 diketahui bahwa ukuran perusahaan tidak memiliki pengaruh terhadap komite manajemen risiko yang terpisah. Hal ini disebabkan karena nilai signifikansi untuk variabel ini adalah 0,484lebih besar dari 0,05. Maka dapat dikatakan bahwa hipotesis kelima ditolak dan hasil penelitian ini tidak mendukung hipotesis yang diajukan.

Besar kecilnya perusahaan tidak dapat mengindentifikasikan kecurangan ataupun risiko-risiko yang dapat terjadi di dalam perusahaan. Perusahaan dengan ukuran besar pada umumnya cenderung mengadopsi praktek corporate governance yang lebih baik dibandingkan perusahaan kecil, sehingga perusahaan besar akan menjalankan fungsi pengawasan lebih baik dibandingan perusahaan kecil dalam menghadapi risiko - risiko yang dihadapinya. Ini membuat perusahaan besar merasa telah mampu menangani segala risiko yang akan dihadapinya dan tidak mendorong untuk membentuk suatu komite, terutama komite manajemen risiko yang terpisah dengan audit. Pembentukan komite manajemen risiko yang terpisah tidak hanya diukur oleh ukuran perusahaan semata. Ukuran perusahaan juga tidak bisa menginterpretasikan risiko keseluruhan yang akan dihadapi oleh perusahaan. Hasil penelitian ini tidak mendukung penelitian yang dilakukan oleh Andarini dan Januarti (2012), Wahyuni dan Harto (2012) dan Ratnawati dan Setyobudi (2010) menemukan bahwa ukuran perusahaan berhubungan signifikan positif dengan komite manajemen risiko terpisah dengan audit.

\section{SIMPULAN}

\section{Kesimpulan}

Penelitian ini menguji faktor-faktor yang mempengaruhi pembentukan komite manajemen risiko yang terpisah pada perusahaan yang terdaftar di BEI tahun 2010-2014. Berdasarkan hasil analisis dan pembahasan pada bab sebelumnya, maka dapat ditarik kesimpulan sebagai berikut:

1. Ukuran dewan komisaris memiliki pengaruh positif terhadap komite manajemen risiko yang terpisah dengan komite audit.

2. Independensi dewan komisaris tidak memiliki pengaruh terhadap komite manajemen risiko yang terpisah dengan komite audit.

3. Risiko pelaporan keuangan memiliki pengaruh negatif terhadap komite manajemen risiko yang terpisah dengan komite audit.

4. Kompleksitas perusahaan tidak memiliki pengaruh terhadap komite manajemen risiko yang terpisah dengan komite audit.

5. Ukuran perusahaan tidak memiliki pengaruh terhadap komite manajemen risiko yang terpisah dengan komite audit.

\section{Saran}

Saran yang dapat dikemukakan dalam penelitian ini adalah pada penelitian berikutnya dapat menambahkan variabel-variabel lain yang mungkin mempengaruhi pembentukan komite manajemen risiko yang terpisah dengan komite audit. Seperti umur perusahaan, leverage dan jenis industri, jenis industri karena kompleksitas yang ada disetiap jenis industri menyebabkan beberapa industri menghadapi berbagai risiko yang komplek juga, sehingga dibutuhkan komite manajemen risiko terutama yang terpisah dengan komite audit. 


\section{DAFTAR PUSTAKA}

Andarini, P. W. dan I. Januarti. 2010. Hubungan Karakteristik Dewan Komisaris Dan Perusahaan Terhadap Pengungkapan Risk Management Committee (RMC) Pada Perusahaan Go Public Indonesia. Simposium Nasoinal Akuntansi XIII, Purwokerto.

Andarini, P. dan I. Januarti. 2012. Hubungan Karakteristik Dewan Komisaris Dan Perusahaan Terhadap Keberadaan Komite Manajemen Risiko Pada Perusahaan Go Public Indonesia. Jurnal Akuntansi dan Keuangan Indonesia 9 (1).

Aunurrafiq, R. N. S. dan Y. M. Basri. 2015. The Moderating Effect of Goal Setting on Performance Measurement System-Managerial Performance Relationship. Procedia Economics and Finance 31: 876-884.

Badriyah, N., R. N. Sari dan Y.M. Basri. 2015. The Effect of Corporate Governance and Firm Characteristics on Firm Performance and Risk Management as an Intervening Variable.Procedia Economics and Finance $31,868-875$.

Butar Butar, S. 2007. Modul Statistik dan Aplikasi SPSS. Semarang: Fakultas Ekonomi Unika Soegijapranata.

Butar Butar, S. 2014. Reputasi Auditor, Karakteristik Dewan Komisaris, Dan Keinformatifan Laba. Jurnal Akuntansi Bisnis 13 (2): 25-43.

Diani, Yosephine Endah Nur, 2013, "Faktor-Faktor Yang Mempengaruhi Pengungkapan Risk Management Committee", Journal Accounting Analysis Journal, ISSN 2252-6765.

Dyaksa, H.P, 2012, "Analisis Pengaruh Karakteristik Dewan Komisaris dan Karakteristik Perusahaan Terhadap Keberadan Risk Management Committee', Skripsi, Universitas Diponegoro.

Hanifah, Kholifatul, 2013, "Analisis Pengaruh Karakteristik Dewan Komisaris Dan Karakteristik Perusahaan Terhadap Risk Management Committee", Journal Accounting Analysis Journal, ISSN 2252-6765.

Herlantu, Vianika dan Andri Prastiwi, 2014, "Pengaruh Karakteristik Komite Audit, Karakteristik Perusahaan Dan Kompensasi Dewan Terhadap Komite Manajemen Risiko", DiponegoroJournal Of Accounting, Vol. 3 No. 3, Hal $1-14$.

Husaini, dkk, 2013, "Corporate Governance and Enterprize Risk Management: AnEmpirical Evidence from The Unique Two-Tier Boards System ofIndonesian Public Listed Companies", Proceedings of World Business and Social Science Research Conference, ISBN: 978-1-922069-33-7.

Keputusan Direksi PT Bursa Efek, Nomor:Kep-305/BEJ/07-2004, Tentang 
Pembentukan Komisaris Independen menjadi salah satu hal yang diwajibkan bagi perusahaan public yang terdaftar di bursa.

KNKG, 2006, Pedoman Umum Good Corporate Governance Indonesia. Komite Nasional Kebijakan Governance.

Komite Nasional Corporate Governance, 2002, Pedoman Pembentukan Komite Audit, Jakarta.

Krus, Cynthia. M dan Hannah L. Orowitz, 2009, "The Risk-Adjusted Board: How Should the Board Manage Risk', Corporate Governance Advisory, Vol.17 No.2.

Kusuma, Chandra Setya, 2012, "Dampak Karakteristik Dewan Komisaris Dan Karakteristik Perusahaan Terhadap Strukturisasi Risk Management Committee", DiponegoroJournal Of Accounting.

Nugroho, M. D, dan S. Butar Butar. 2013. Pengaruh Karakteristik Dewan Komisaris Dan Kepemilikan Institusional Terhadap Manajemen Laba Berbasis Aktivitas Real. Jurnal Akuntansi Bisnis 13 (2): 1-23.

Pratika, Briana Dita, 2011, "Faktor-Faktor Yang Mempengaruhi Keberadaan Risk Management Committee Terhadap Manajemen Risiko”, DiponegoroJournal Of Accounting.

Peraturan Bank Indonesia, Nomor:5/8/Pbi/2003, Tentang Penerapan Manajemen Risiko Bagi Bank Umum, Gubernur Bank Indonesia.

Peraturan Bank Indonesia, Nomor:8/4/Pbi/2006, Tentang Pelaksanaan Good Corporate GovernanceBagi Bank Umum, Gubernur Bank Indonesia.

Ramadhani, Nila, Ria Nelly Sari dan Edfan Darlis, 2015, "Pengaruh Karakteristik Dewan KomisarisDan KarakteristikPerusahaan Terhadap Praktik Manajemen Risiko Perusahaan", Jurnal Akuntansi, Vol. 4 No. 1, ISSN 2337-431.

Ratnawati, Andalan Tri, 2012, "Analisis Faktor-Faktor Yang Mempengaruhi Keberadaan Komite Manajemen Risiko (Risk Management Committee)", Journal Media Ekonomi dan Manajemen, Vol. 26 No. 2.

Ratnawati, Andalan Tri, dan Setyobudi, 2012, "Analisis Good Corporate Governance dan Karakteristik Perusahaan Terhadap Keberadaan Komite Manajemen Risiko Independen (Separate Risk Management Committee) Pada Perusahaan Yang Listing Di BEI", Jurnal Ilmiah UNTAG, Semarang.

Safitri, Ana Khusnun, dan Wahyu Meiranto, 2013, "Analisis Faktor-Faktor Yang Mempengaruhi Pembentukan Risk Management Committee", DiponegoroJournal Of Accounting, Vol. 2 No. 4, Hal 1-12.

Sambera, Gea Fatah, 2013, “Analisis Pengaruh Karakteristik Dewan Komisaris 
Dan Karakteristik Perusahaan Terhadap Pembentukan Komite Manajemen Risiko", Skripsi Universitas Diponegoro.

Susiana Dan Herawaty. 2007, "Analisis Pengaruh Independensi, Kualitas Audit, Serta Mekanisme Corporate Governance Terhadap Integritas Laporan Keuangan”, Simposium Nasional Akuntansi X, 26-28 Juli.

Utomo, D.F., 2012, “Analisis Pengaruh Karakteristik Dewan Komisarisdan Karakteristik Perusahaan TerhadapPengungkapan Risk Management Committee (RMC), Skripsi, Universitas Diponegoro.

Wahyuni, Tri dan Puji Harto, 2012, "Analisis Pengaruh Corporate Governance Dan Karakteristik Perusahaan Terhadap Keberadaan Komite Manajemen Risiko", DiponegoroJournal Of Accounting, Vol. 1 No. 2, Hal 1-12.

Wulandari, Paramastri, 2012, "Pengaruh Karakteristik Komite Audit Terhadap Pembentukan Risk Management Committee", Skripsi, Universitas Diponegoro.

Yatim, P., 2009, “Audit Committee Characteristics and Risk Management of Malaysian Listed Firms", Malaysian Accounting Review, Vol. 10 No. 1, PP 5-9. 